\title{
Reading the End-of-life Controversy through Political Lenses: Public Power and Intimacy
}

\author{
Anna Dumová
}

\begin{abstract}
This article presents end-of-life controversies as a site through which we can disclose the operation of public power. Reviewing some recent political negotiations on end-of-life decisions (such as withdrawal treatment or the legalization of euthanasia), the article investigates the particular role that an intimate experience with the end of life plays in those political negotiations. As the collective acknowledgement of the individual emotional experience with body and mind during the end of life, intimacy enables us to conceive the nature of public power in the mutual engagement between the collective and the individual. Since this has an impact on the dynamic of political negotiations, the article concludes by suggesting that Western liberal democracies are facing not a disappearance of politics but a transformation of public power through intimacy.
\end{abstract}

KEYWORDS biopolitics, discourse, end of life, intimacy, public power, Foucault, interpretive political science

\section{Introduction}

In 2005, the whole world could follow live the highly emotional controversy over whether or not the American Terri Schiavo's feeding tube should be removed (as Quill [2005] analyzes). Photos of an inert woman being caressed by her parents sitting at her bedside alternated in the media with speeches and argumentations by priests, doctors, and politicians about whether life in a persistent vegetative state, as was Terri's, was a "life with dignity". During the same period of time, the French Parliament had been debating a law regulating end-of-life decisions in response to the emotional media case of a young fireman, Vincent Humbert, who in 2003 had written an open letter to the president claiming his "right to die". With that letter, Humbert publicly raised the question of the legal possibility of "active euthanasia" and showed, once again, the central role of autonomy in end-of-life debates (see Durnová and Gottweis 2009). In the years to follow, both European and US politics would experience manifold similar cases of people suffering from incurable diseases or being limited in what they label as the capacity to lead a "life with dignity" launching hotly debated controversies dealing with the questions of who has authority over these decisions and how both autonomy and dignity should be understood in the current era of Western liberal democracies.

Sociální studia / Social Studies 1/2016. Pp. 87-100. ISSN 1214-813X. 
The present reflection aims neither to encompass these rich and heterogeneous discussions nor does it pronounce ethical judgments on respective decisions concerning the end of life (such as the legislative status of "assisted suicide" or "active euthanasia", or the legal frameworks for treatment withdrawal). The cases mentioned above expose the fact that the societal debate on end-of-life issues is no longer a question exclusively of ethics; instead, the ethical values of dignity and autonomy have materialized in Western societies as a result of political negotiation of the particular social, historical, and cultural conditions in which people die. Considering these political negotiations through discursive practices ${ }^{1}-$ as they become apparent in debates, legislation, strategy papers issued by institutions or civic associations, as well as through media coverage of end-of-life controversies - this article explains how intimate experience intervenes in this process.

The following reflection builds on the background of the current Western discourse on death and dying, where end-of-life issues have been simultaneously considered as intimate issues (see the works of Ariès 1980; Berger 1969; Amundsen 1989; Noys 2005; Lupton 2003; or the review of the debate in Vido 2011). The recent political negotiations over end-of-life choices reveal to us how that intimacy itself becomes a site of politics. This article takes up what has been loosely referred to as the interpretive tradition in political science ${ }^{2}$ - which has abundantly argued that discursive practices are revelatory of the nature of public power because they shape policy arguments, practices and instruments (Dryzek 1993; Hajer and Wagenaar 2003; Fischer and Gottweis 2012; Howarth 2010; or Yanow 1996), and argues for an understanding of the end-of-life controversy as a site through which we can denude the way public power operates.

The end-of-life examples illustrate for us here how public power is exerted with and through the intimate experience of the end of life. "Intimacy" refers here to the discursive practice by which a particular collective acknowledges the individual's emotional experience (as argued by Giddens 1992; Sexton and Staudt Sexton 1989; Zelizer 2005) with death and dying, thereby encompassing both the material and non-material aspects of this experience. Although the role of intimacy for politics has been touched upon in works on gender and family policies (Martin 2001; Roseneil 2010), the focus on intimacy in the end-of-life controversy goes beyond gender-specific roles of intimacy to point out the mutual engagement between the collective and the individual, which is essentially the nature of public power in liberal democratic policy regimes.

To reflect on the nature of public power is crucial here for showing that end-of-life controversies demonstrate that Western liberal democratic policy regimes are facing not a disappearance of politics but a rearrangement of politics by relocating public power into the

The terminology in the approaches using "discourse" as the lens through which to view and interpret policy processes has varied in recent decades. The term "discursive practice" is used here in order to avoid any misunderstandings between the notion of discourse as a product of verbal interactions and other textual practices and discourse as the active agent shaping our view of social reality thereby implicitly relativizing the notion of "social reality". Discursive practices shape views of social reality in the first place.

2 For an overview of the approach through discourse in public policy in the Czech context, see Durnová (2011b). 
sphere of intimacy and by affecting in that way the dynamic of political negotiations. In so doing, this article extends the debate on death and dying that has occurred in the social sciences (such as Clark 2002; Kaufmann and Morgan 2005; Kearl 1989; Kübler-Ross 2009; Malý 2011; Noys 2005), as it shifts the focus from the values of dignity and autonomy to the notion of public power through which these values come into being and open the terrain for intimacy. Furthermore, although there have been studies on discourses of death (Carpentier and Van Brussels 2012) and on the political nature of the end-of-life debates that define these issues as controversies (Green-Pedersen 2007; Engeli, Green-Pedersen and Larsen 2012), to date such studies have not focused on the role of intimacy.

The first section of this article sets the stage for understanding why it makes sense to read the end-of-life controversy through political lenses and focus on the nature of public power. The second part offers an overview of some recent end-of-life cases that dominated the media in the United States and in Europe, in order to show how autonomy and dignity have been used by all actors as arguments to advocate for a particular end-of-life decision, be it for or against self-chosen death. The third part then reveals the role of intimacy in the presentation of both these values based on the results of analysis of media coverage, expert interviews and relevant policy documents done in earlier studies on end-of-life debates (Durnová 2011a, 2011b and 2013). The cited end-of-life examples are suggestive rather than comprehensive, and they demonstrate the plausibility of the theoretical reflection elaborated herein. The article concludes by clarifying the main conclusions we can draw from the case of end-of-life controversies about the mutation of public power that is currently taking place in liberal democratic policy regimes.

\section{The political face of the end-of-life controversy}

In recent works of political thought, the role of death in the Western political order has been seen as the outer limit of political regulation, beyond which power is no longer exercised (Agamben 1998; Murray 2006; Dean 2002) or as something with an essentially sacred character that therefore places it outside of everyday human existence (as argued for example by Douglas 1966; Durkheim 1971). ${ }^{3}$ This consideration of death and dying fundamentally changed with Michel Foucault's introduction of the concept of biopolitics (e.g. Foucault 1997), which stipulates that the key capacity of death is to create a symbolic order that stratifies society. According to this view, the political face of death detaches itself from the somewhat traditional dimension of morality politics and advances the power relation postulated between the individual and the collective.

This reflection considers solely the Western context of policies on the end of life. This does not suggest in any way that the plurality of historical and philosophical axes influencing the debates in Asia or Africa should be neglected. Several narratives - religious and secular - have provoked interesting discussions on euthanasia and self-chosen death and have influenced to some extent the general debate in the Western world. In the interest of remaining within the bounds of the study and given the focus on policy regimes in the Western world, the present overview cites only examples from that tradition. 
Foucault reveals how this limit of political regulation has been mitigated by the border between the dead and the living. Whereas the traditional power scheme of the political authority decided between "letting live" and "making die", Foucault argues that modernity has altered this scheme by subverting this mechanism and changing its nature from the line between "letting live" (reprieve) and "making die" (punishment) to the border between "making live" (treatment) and "letting die" (no more treatment) (Foucault 1997). The struggle to define what is to be made to live and what is to be allowed to die is by no means an exclusive question of purely biological criteria but is articulated through historical, ethical, cultural and scientific discursive practices, as many scholars using Foucault's concept have later shown in their analysis of health issues (e.g. Gottweis 1998; Memmi 2003; Nettleton 2000; Rose 2007). Indeed, this struggle of discursive practice interfering in and shaping the debate is central to the nature of public power that appears along with biopolitics. The power shaping and shaped by discursive practices namely entails questioning how the line is drawn between "normal" bodies and those that, for whatever reason, are considered not normal. How and where that line is drawn encompasses history, culture, ethics, spirituality, and in particular power agencies.

Agamben (1998) develops this notion of power in relation to the value of dignity central to the Western debate on the end of life - by explaining that the phrase "death with dignity"4 implies that the dying subject has value. When the death is of someone in a concentration camp, of some other prisoner, or indeed of any subject to whom has been attributed by a group or by the whole society - a limited or modified value of dignity, the specific process of how dying is conceived and evaluated is impacted. ${ }^{5}$ As Agamben points out toward the end of Homo Sacer, it is important to understand these historical practices as stemming from a concept of life as something that is "worthy" (as Murray 2006 and Lemke 2003 also argue). Although the "worth" of life has become negatively connoted through the historical experience with genocides, and these negative references enter current debates on end-of-life controversies, it is essential to understand that a life's "worth" builds on a notion of death as an apparatus that denudes the classifications of good, bad, normal and relevant, regardless of the ethical tone in which these terms are used and concrete classifications are carried out.

In order for us to understand the nature of this classification of historical, ethical, scientific and cultural discursive practices, it is necessary to analyze how a particular form of death

4 Although Agamben does not name the zone explicitly, he links death to the notion of "life" by engaging the double face of life as "bios" and as "zoe". He enters the area of dignity by reflecting the "coma" and "coma dépassé" that brings a new notion of "bare life", which is nevertheless retrospectively seen as "bios".

5 Similar observations were revealed in manifold analyses of the history of the practice of medical experimentation on bodies that were not seen, by the particular society or at the particular period of time, as possessing enough dignity to warrant more considered treatment (Lemke 2003 and Dean 2010). In modern history, this evaluation of life can be seen mainly in the conception of the T4 program of euthanasia in Europe during the Second World War, in which mentally or physically disabled persons were brought to centres where they were killed by lethal injections. The lives of patients killed in those establishments had been deemed at the time as "not worth living" (in German, "unwürdig" [Lemke 2003]). 
or dying is seen as "normal" and "good," and for whom it is seen as such. The classification becomes more complex if we disclose, as Agamben also suggests, that the current debate on self-chosen death defines the act of killing someone not as a murder, punishment, or genocide, but as an expression of "mercy" and "compassion" (Agamben 1998: 174). By integrating this emotional dimension and respect for someone's will, we focus on the individual who takes part actively in the classification of good, bad, or normal. It follows that each and every end-of-life policy responds to a certain mode of governing the individual and not only becomes evidence of concrete discursive practices arguing for a particular end-of-life choice but, at the same time, highlights the individual's perspective based on his/her intimate experience, conveying these discursive practices.

That is what Foucault showed in his late work on the "empowerment of the self", by stating that public power appears through the negotiation of discursive practices that the individual adopts, rejects, or revises (cf. Foucault 2008). Targeting the intimate experience of end-of-life issues such as anxiety, hope, and frustration related to the end of life means then to go beyond the contours of the empowerment of the self and to look at how the individual emotional experience of the self is acknowledged or not, and by whom it is acknowledged in the respective negotiations of discursive practices. Doing so can elucidate the peculiarities of public power through which political institutions try to permit, maintain, or reverse concrete end-of-life choices.

\section{Westem discourses on the end of life: autonomy and dignity}

It follows from this theoretical discussion that, when observing current end-of-life debates be it in the media, in political discussions, or in expert debates - we look on them not as some sort of moral or ethical guidelines but as regimes that govern the individual's relation to society, and society's relation to the individual. These regimes govern through various sorts of discursive practices that interact with each other in the debates.

Such an insight into end-of-life debates takes into account history, culture, and specific spatiotemporal political contexts to which particular policies seek to respond. In such an insight, ethical and moral questions are but some of many components of the debate. To follow this insight through discursive practices is to specify how all these contextual elements interact with each other and to focus on the nature of public power confronting us when the end-of-life issue is debated or when concrete policy instruments and agendas are proposed. In this sense, current end-of-life controversies are co-produced through historical and sociopolitical developments, scientific knowledge, and networks of professional associations, as much as they are accompanied by actual advocacies for challenging or consolidating these developments.

In the Western political landscape related to the end-of-life issue, autonomy and dignity are being used as key drivers for such advocacies, regardless of which end-of-life choice is being argued for (see also Schicktanz et al. 2010). To begin with, advocates for self-chosen death who fight to extend personal rights to include a right to die argue that against the background of "life being no longer what it used to be" for some people, self-chosen death should be both legally and morally permissible. Right-to-die movements - such as the one in France 
stemming from Humbert's case and including the ensuing national debate on the end-of-life law - introduce into the debate arguments and narratives that place the ethical values of dignity and autonomy at the forefront of politics, thereby reshaping the context in which they become apparent.

Everyday practices in hospices, hospitals, and special-care units for the terminally ill demonstrate another aspect of the political forefront of autonomy and dignity. The increasing numbers of deaths in hospital settings - compared to the decreasing numbers of at-home deaths and the declining number of multigenerational homes that once provided a care network at the end of life - have anticipated the transformation of the end-of-life sector by intensified individual participation in care. This can be seen in the question of how to finance care at the end of our lives (Memmi 2003) and in the expectation that individuals will assume the organizational tasks previously assumed by institutions (as argue Nettleton 2000; Rose 2007). Such a role for the individual reshapes these ethical values and anticipates, to a large extent, the idea of self-chosen death because it exposes individual choice as a legitimate approach to determining one's own care.

Autonomy and dignity are both anchored in the legislative texts of Western liberal democratic regimes, be it through the Universal Declaration of Human Rights or through specific laws that refer to these values. This importance and relevance of both dignity and autonomy for the context of Western discourse on end of life can be explained by two anecdotes: First, in 2007, the Royal Academy of Arts and Sciences in the Netherlands began a major survey in European countries concerning values, including a question asking people to predict how acceptable euthanasia would be by the year 2020 . Over $60 \%$ of respondents estimated that it was very probable that euthanasia would be legal in the majority of European countries by 2020; this point represents perhaps the most fundamental autonomous choice people might have in their lives. ${ }^{6}$ This survey resonated with Inglehart's comprehensive surveys on Western values in 1971 and 2008 (Inglehart 2008), which supported the appearance of autonomy and dignity in Western post-materialist societies not only as end-of-life related values but also as crucial values in liberal democratic regimes.

In the second anecdote, in 2012 the New York Times organized an opinion debate on end-of-life issues, inviting key experts and civic activists to make a case for their positions. The debate provided a useful summary of the usual arguments on the issue in the Western discourse: the notion of "dignity" was highlighted as a premise against the slippery slope, and the idea of "deliberative ending of a life" was observed - in the context of the unbearable situation of terminally ill people - as, again, a dignified choice that ends suffering. Moreover, both argumentation camps in the New York Times debate criticized the health-care systems in Western liberal democracies, which is an aspect of all end-of-life debates in the Western world.

Both the Netherlands study and the New York Times debate reveal that in recent decades the focus has shifted to "dignity", which is articulated both as the possibility of allowing death to come in its own time and, conversely, as representing an individual's choice of when

6 Study of the Royal Dutch Academy of Science, published in 2007 in the Council of European Social Science Data archives: http://www.cessda.org/. 
to die. Seen through the lenses of discourse, the "end-of-life" label encompasses political debates and negotiations both about the regulation of care for the terminally ill and about allowing self-chosen death and how in the public debate both aspects originate from the same requirement for dignity. At the same time, inherent in both anecdotes is the dimension of an autonomous choice that has become key in the current debates about new practices of care for terminally ill people, as well as in debates on euthanasia policies and assisted-suicide policies. These aspects rearticulate "autonomy" and invite us to consider more carefully the argument of society's obligation toward the individual by emphasizing the intimate dimension of the political controversy that appears through the relation of the individual to the society.

Through this optic, we see that focusing solely on autonomy and dignity does not explain the debate because doing so can imply completely opposite end-of-life choices. Rather, what has recently been framed by various media and policy actors all around the Western world as the "end-of-life controversy" is an interaction of different discursive practices that - while referring to both autonomy and dignity - increasingly incorporate the intimacy of death and dying in their argumentation. Current end-of-life controversies are discussed and performed both in terms of the cultural and the social contexts they stem from and in terms of how their demands for revision bring to the fore a changed notion of public power that operates with and through intimacy related to death and dying.

\section{Intimacy and the mutation of public power}

As can be seen in the cases and anecdotes referenced above, end-of-life issues touch on the social environment in which dying occurs, or should occur, and reveal how dying affects our lifestyle choices and is affected by them. The values of dignity and autonomy stem from this imaginary of end-of-life issues and account for it. In a nutshell, the end of life is shaped by discursive practices as they develop across various kinds of knowledge on the topic. Analyzing end-of-life decisions through discursive practices necessarily goes beyond the legal question of what is allowed and not allowed, and beyond the ethical question of what should or should not be allowed. Indeed, what is examined through discursive practices is "good dying" as the symbolic order, and the particular ways in which we negotiate support for it or demand revisions of this symbolic order.

However - and herein lies the challenge of public power - since end-of-life issues are also intimate issues, the intimate dimension of the end of life encounters the discursive shape of dignity and autonomy. Following studies of emotional experience in sociology, public policy, and gender studies (Giddens 1992; Hochschild 2003; Roseneil and Budgeoun 2004; Sexton and Sexton 1989; and Zelizer 2005), intimacy is being defined as the individual emotional experience involving both body and mind during the end of life, an experience that is transmitted through discursive practices and may, and may or may not be acknowledged by a collective. Albeit usually considered only in the context of sexual relationships, intimacy relates here, thus, to concern about the appropriateness of a particular emotional experience in various situations for our fellow persons at the end of life and refers to both material and non-material practices related to death and dying. 
Intimacy is part of end-of-life debates because it affects the presentation and negotiations of particular end-of-life choices by classifying what is "relevant", "normal", or "good", and it offers arguments for why it is "relevant" or "normal". Consequently, intimacy also shapes the way actors are presented and understood in related end-of-life debates because it groups them by particular discursive practices according to who acknowledges which sorts of individual emotional experiences.

By bringing forward the role of individual emotional experience - and we can see this in the emphasis placed on the individual emotional experience in media stories as well as in speeches by stakeholders or the strategy papers issued by institutions - intimacy disturbs the established symbolic order of the Western discourse on death, which instead presupposes silence on this dimension. Intimacy disturbs because it reunites the political and the intimate dimensions of the end of life, which coexist only uneasily in that same Western discourse. Be it the intimacy of our loved ones' dying or the dying of strangers whose intimate stories we follow through the media, this experience becomes contrasted with the traditional notion of political negotiations. This traditional view is two-pronged: first, the intimate, although recognized as the intimate (as, for instance, in all sorts of gender policies), is still understood as occupying an area separate from technical and pragmatic solutions; second, the intimate and the rational should at the least acquire clear and distinct contours of what is what. This contrast between intimate and political creates a tension expressed throughout all the current political debates on conditions of treatment withdrawal or legalizing euthanasia.

This tension represents a crucial boundary between the collective and individual dimensions of the end of life, which brings us to the notion of public power. Initially, this power is located on the level of end-of-life discourses in the sense that we can observe that values, beliefs, and interests are presented as arguments for "good" dying, and support - or oppose the particular symbolic order that we classified earlier using a Foucauldian approach. Since the same values are employed in end-of-life discourses by the opposing side, the acknowledgment of a particular individual emotional experience of death and dying becomes crucial because it gives us the reasons and arguments that these values, beliefs, and interests are used in support of or in opposition to a particular symbolic order.

Thus, public power gets rearranged in the way that it operates through the process of how the individual emotional experience is acknowledged, or is not acknowledged, and what arguments are given to support or to deny this acknowledgment. By design, the acknowledgment denudes how actors position themselves, what particular stories they adhere to, and how they interact in the competition between discourses in order to make the symbolic order they support appear to be the "good one". Simultaneously, this mutation of public power can be seen as a prolongation of Foucauldian biopolitics by engaging the negotiation of the symbolic order on the boundary between the individual (together with his/her intimacy) and the surrounding collective.

Let us briefly review some details of the Terri Schiavo case in order to see intimacy in action. Terri had been diagnosed as being in a vegetative persistent coma. Whereas Terri's husband saw her medical condition as the reason to withdraw her feeding tube because it was what his spouse would have understood to be a life without dignity, he said - Terri's parents argued that Teri would have chosen to stay alive, and therefore should have 
been maintained on life support. Their point of view found support in President George W. Bush, as well as in arguments made by the Roman Catholic priests and bishops who publically stated their position on this case.

Now, vegetative coma is a complicated and medically ambiguous borderline state between dead and alive, and its classification changes as the medical research develops. The complexity of this border played into the interaction of distinct layers of knowledge - the legal, the medical, the intimate - that was presented by various actors during the debate. This interaction showed one key point that spanned all arguments for or against the withdrawal of her feeding tube: the respective intimate experience with Terri's story of her family and the bystander end-of-life experiences of all the other actors involved. As articulated in the media interviews and speeches of all the involved actors as well as performed via photographs of Terri with her family (see also Quill 2005), this experience was used to argue for Terri's autonomy and dignity.

On the personal level, this included the stories of both her husband and her parents, each of whom argued that they "knew" or "could understand" how Terri felt, what she would do in their place, and so on. Their argumentations were linked to their intimate experiences with Terri's situation insofar as they presented these experiences as guarantees of their own good and true intentions, even though they in fact arrived at diametrically opposed conclusions.

The reference to intimate experience was not limited to these personal stories but was brought to the expert level, as well. Claims about emotional experience were made by medical professionals and religious authorities. In their argumentations they recalled "empathy" with Terri or with the family because that is what is needed when the end of life comes to the fore, or they referred to the "spirituality" that relates to these situations. In addition to their roles as experts, the references to these notions placed the experts in the position of those who know that the end of life is usually difficult and who propose, through their references to the emotional experience of end-of-life cases, guidelines on what should be done.

We can further demonstrate the process of acknowledgment of the individual emotional experience and the way it shapes public power by touching briefly on the other example mentioned earlier, the French case of Vincent Humbert. On September 25, 2003, the popular French newspaper France soir published Humbert's statement: "Mr. Chirac, I claim the right to die". The quadriplegic Humbert dictated it with the only part of his body he could move: his thumb. French President Jacques Chirac denied his wish, and this affair raised an intense, emotional discussion across French society about legalizing euthanasia. A parliamentary enquiry was established the same year, tasked with proposing a law to resolve the controversy. The subsequent "end-of-life law", based on input from medical experts, ecclesiastical authorities, and ethicists, retained the punitive stance toward euthanasia in France and was unanimously passed by the French Parliament in April 2005. Public opinion polls since the initial 2003-2005 debates have shown that the French population increasingly favours legalizing euthanasia. Such polls were among the factors resulting in a reconsideration of the "end-of-life law" between 2012 and 2014, which suggested more relaxed stances toward withdrawal of treatment and the administration of sedatives for patients in the terminal state of their lives. 
The French debate on euthanasia reveals more than a simple discussion of pros and cons of the various end-of-life decisions. It exposes the underlying conflict between the regulatory demands and the individual emotional experience with the end of life, a conflict that shaped the development of the discussions in France. A closer look at the groups for and against euthanasia discloses a consistent division of actors. Whereas all the actors against euthanasia were established authorities (the parliament and other state institutions, professional association, religious authorities, etc.), the actors advocating for euthanasia were represented by singular media stories of patients, similar to Vincent, and civic patient associations (for details see Durnová 2011a).

Further, the way these actors have consolidated their positions in the French debate reveals how public power operates through intimacy and is legitimized by it. Both autonomy and dignity are presented and understood through the process of acknowledging the respective individual emotional experience: it is important to look at who is acknowledging the latter. Vincent Humbert claims the right to die, and by that statement he openly asks the institution to acknowledge his individual emotional experience with the end of life, resulting in the wish to end his life. Rather than respecting his wishes, experts and politicians view them with suspicion and cast him in with other patients whose wishes to die are seen as "dangerous"7 or as not "really meaning that". 8

However, Humbert's emotional experience had been acknowledged by others in the French debate. The discourses of private associations (mainly the Association pour le droit de mourir dans la dignité [Association for the Right to Die with Dignity) and the media debate supported euthanasia advocates by using Vincent Humbert to blame the French political establishment for "ignoring citizens' concerns". These two views on Vincent's emotional experience visualize for us nicely the conflict between two visions of what the end of life should be. These views are projected in the discursive practices that have emerged from the expression and reception of Vincent's emotional experience. Their differences and interactions turn our focus to the power relations through which such demands concerning end-oflife issues are presented.

These discursive practices, then, are projected in the French political debate as a conflict between the individual wishes of the citizen and the collective aims of institutionally established actors (for details see Durnová and Gottweis 2009). A study of all related documents and the media coverage following both Humbert's case and adoption of the end-of-life law shows that on one side could be found, together with the politicians, experts from the field

7 This argumentation is pursued also by the L'Alliance pour les Droits de la Vie [Alliance for the Right to Life]: http://www.adv.org/lactualite-de-lalliance/etats-generaux-de-la-bioethique/tournee-bioethique-le-bilan/ (accessed July 17, 2009).

$8 \quad$ The respondent further explains: "We have to be careful of what people say, in which situation [they say it] and what is the nature of the answer they want to have." Interview in the French hospice Réseau Quiétude.

9 The analysis of the French media discourse was done in the following journals and magazines (09/2003 - 08 /2008): Le Monde, Le Figaro, Libération, Nouvel Observateur, Zenit, genethique.org (an online magazine for information on genetics and bioethics), 20 Minutes, L'Express, France Société, Lifenews.com (for comments about France), and l'Humanité. 
(physicians, nurses, and end-of-life care staff) who supported the "end-of-life law", and on the other side were citizens, media coverage, and private associations that had not been able to participate in the formulation of the law and that criticized the law for not taking into account their points of view.

The question that emerges from the French debate is whether the increasing inclination toward euthanasia is a result of the popularity of this end-of-life practice or instead the result of the French political establishment failing to acknowledge the discursive practices of the public which depict advocacy for euthanasia as an individual emotional experience. The Terri Schiavo case also shows that this site of individual emotional experience is in conflict with the political establishment: it was the example of a deeply personal story that developed into a political story, one starring none other than the U.S. president and the nation's Supreme Court, and surely it will not be the last. In both these examples, one might well ask how these institutions came to wield the authority to take what is, practically speaking, a medical expert decision that many doctors face in their everyday practice. The fact that institutions have to make the highly emotional and intimate decisions that many families struggle with at the end of their loved ones' lives affects public power by bringing it into a close and difficult relation with intimacy, through which the institution needs henceforth to operate and seek legitimacy.

Intimacy - performed through the emotional experience that actors expect to be acknowledged by the surrounding collective - is a site for politics because - if the political dimension of the end of life consists in establishing the symbolic order of "good dying", as the Foucauldian approach argues - the nature of this symbolic order results from the way individual emotional experience is acknowledged. This does not mean that intimacy should incorporate a particular end-of-life choice, nor does it automatically respond to a particular type of institution. Intimacy is a site for politics because it shapes the way actors are distributed in the respective arguments, it shapes the way the groups interact with each other, and it offers a particular understanding of autonomy and dignity that have become ambivalent in the Western discourse on death and dying as we see in both the French and U.S. examples.

\section{Conclusion}

The primary concern of this article is to offer a reading of current end-of-life controversies, which enables us to investigate the nature of public power that operates within them. Current works on end-of-life issues primarily discuss the way we die or will die, and what we ought to do according to our historical, social, and cultural backgrounds, thus failing to explain the role of public power that organizes these backgrounds as "relevant" or "normal" forms of understanding the end of life. This article suggests a mechanism for us to think about public power operating with intimacy and being legitimized through the latter. The call for such a notion of public power implies considering the process of if and how intimate experience related to the end of life interacts within existing discursive practices, and how it serves as an impulse for particular understandings of autonomy and dignity, thereby either revising or, conversely, consolidating discursive practices related to the end of life.

Such a reading of the end-of-life controversy has two implications for understanding the rearrangement of politics and the related relocation of public power in Western liberal 
democratic regimes. On the one hand, it shows us that politics can and must be understood outside of its institutional contours (as Connolly 2013 argues on a theoretical level). This article brings forward an understanding of politics through the nature of public power. In an analogy to Foucault's figures of biopolitics and the empowerment of the self through which he shows that bodies are negotiated by means of practices that the individual adopts, rejects, or revises (Foucault 1997 and 2008), this article targets intimate experience and calls for highlighting it as an element of public power.

By focusing on the process of acknowledgment of the individual's emotional experience with the end of life we challenge the limits of defining rational actions, or labelling them as such by political actors for the understanding of political consequences. This suggests the need for more careful study of the intimate experience, not as a counterpart to "rational" evaluations of the consequences of the emotions presented by patients, their families, and the wider community, but as a spanning element in the relation between the collective (or people acting for the institution of the state) and the individual and thus as an essential part of public power.

However, such a political reading does not mean that ethical discussions around the endof-life controversy are weakening, and neither does it suggest that public power has disappeared from its common institutional boundaries. Rather, the reflection shows that in the case of end-of-life controversies, public power may use strategies other than morality politics, much as it interacts within types of knowledge other than those distributed by state actors. Turning our focus to the nature of the interaction among the various actors in political debates reveals that the mutation of public power has in turn swung politics toward new spheres of interactions and legitimization of its actions including, henceforth, intimacy.

\section{References}

AGAMBEN, Giorgio. 1998. Homo Sacer. Stanford: Stanford University Press.

AMUNDSEN, Darrel W. 1989. "Suicide and Early Christian Values." Pp. 77-154 in Suicide and Euthanasia: Historical and Contemporary Themes, edited by Baruch A. BRODY. Dordrecht: Kluwer Academic Publishers.

ANNAS, George J. 1995. "The Right to Die in America: Sloganeering from Quinlan and Cruzan to Quill and Kevorkian." Duqesne Law Review 34(4): 875-897.

ARIÈS, Philippe. 1980. L'homme devant la mort. Paris: Le Seuil.

BERGER, Peter L. 1969. The Sacred Canopy: Elements of a Sociological Theory of Religion. Garden City: Doubleday.

CARPENTIER, Nico and Leen VAN BRUSSEL. 2012. "On the Contingency of Death: A Discourse-Theoretical Perspective on the Construction of Death." Critical Discourse Studies 9(2): 99-115.

CLARK, David. 2002. "Between Hope and Acceptance: The Medicalisation of Dying." British Medical Journal 324: 905-907.

CONNOLLY, William E. 2013. The Fragility of Things: Self-organizing Processes, Neoliberal Fantasies, and Democratic Activism. Durham, NC: Duke University Press.

DEAN, Mitchell. 2010. Governmentality: Power and Rule in Modern Society. London: SAGE.

DOUGLAS, Mary. 1966. Purity and Danger. London: Routledge \& Kegan Paul. 
DRYZEK, John S. 1993. "Policy Analysis and Planning: From Science to Argument." Pp. 213-232 in The Argumentative Turn in Policy Analysis and Planning, edited by Frank FISCHER and John FORESTER. Durham, NC: Duke University Press.

DURKHEIM, Émile. 1971. The Elementary Forms of the Religious Life. London: Allen \& Unwin.

DURNOVÁ, Anna and Herbert GOTTWEIS. 2009. "Politik zwischen Tod und Leben". Pp. 273-303 in Bios und Zoe. Die menschliche Natur im Zeitalter ihrer technischen Reproduzierbarkeit, edited by Martin WEISS. Frankfurt/M.: Suhrkamp.

DURNOVÁ, Anna. 2011a. "Feldforschung Intim: Von Erlebnissen, Bedeutungen und Interpretationspraxis in der Politikfeldanalyse." Österreichische Zeitschrift für Politikwissenschaft 4: 417-432.

DURNOVÁ Anna. 2011b. "Diskurzivní př́stupy v Policy Analysis." Pp. 64-104 in Současné metodologické otázky veřejné politiky, edited by Martin NEKOLA, Hanna GEISSLER and Magdalena MOURALOVÁ. Praha: Karolinum.

DURNOVÁ, Anna. 2013. "Governing Through Intimacy: Explaining Care Policies through 'Sharing a Meaning." Critical Social Policy 33(3): 494-513.

ENGELI, Isabelle, Christoffer GREEN-PEDERSEN and Lars T. LARSEN. 2012. Morality Politics in Western Europe: Parties, Agendas and Policy Choices. London: Palgrave Macmillan.

FOUCAULT, Michel. 1997. "Il faut défendre la société" cours au Collège de France, 1975-1976. Paris: Gallimard le Seuil.

FOUCAULT, Michel. 2008. Le Gouvernement De Soi Et Des Autres Cours Au Collège De France, 19821983. Paris: Gallimard Le Seuil.

GIDDENS, Anthony. 1992. The Transformation of Intimacy. Cambridge: Polity.

GREEN-PEDERSEN, Christoffer. 2007. "The Conflict of Conflicts in Comparative Perspective: Euthanasia as a Political Issue in Denmark, Belgium, and the Netherlands." Comparative Politics 39(3): 273-291.

HAJER, Maarten and Hendrik WAGENAAR. 2003. "Introduction." Pp. 1-30 in Deliberative Policy Analysis: Understanding Governance in the Network Society, edited by Maarten HAJER and Hendrik WAGENAAR. Cambridge: Cambridge University Press.

HOWARTH, David. 2010. "Power, Discourse, and Policy: Articulating a Hegemony Approach to Critical Policy Studies." Critical Policy Studies 3(3-4): 309-335.

GOTTWEIS, Herbert. 1998. Governing Molecules: The Discursive Politics of Genetic Engineering in Europe and the United States. Cambridge, MA: MIT Press.

HOCHSCHILD, Arlie R. 2003. The Commercialization of Intimate Life: Notes from Home and Work. Berkeley: University of California Press.

INGLEHART, Ronald F. 2008. "Changing Values among Western Publics from 1970 to 2006." West European Politics 31(1-2): 130-146.

KAUFMAN, Sharon and Lynn MORGAN. 2005. "The Anthropology of the Beginnings and Ends of Life." Annual Review of Anthropology 34(1): 317-341.

KEARL, Michael. 1989. Endings: Sociology of Death and Dying. Oxford: Oxford University Press.

KÜBLER-ROSS, Elisabeth. 2009. On Death and Dying: What the Dying Have to Teach Doctors, Nurses, Clergy and Their Own Families. New York: Routledge.

LEMKE, Thomas. 2003. "Rechtsubjekt oder Biomasse? Reflexionen zum Verhältnis von Rassismus und Exklusion.” Pp. 160-179 in Biopolitik und Rassismus, edited by Martin STINGLEIN. Frankfurt/M.: Suhrkamp Verlag.

LUPTON, Deborah. 2012. Medicine as Culture: Illness, Disease and the Body in Western Societies. London: SAGE.

MALÝ, Tomáš. 2011. "Rituál smrti a Sociální praxe ve věku konfesí, Historicko-antropologická perspektiva." Sociální studia 8(2): 15-23.

MARTIN, E. 2001. The Woman in the Body: A Cultural Analysis of Reproduction. Boston: Beacon Press. 
MEMMI, Dominique. 2003. "Governing through Speech: The New State Administration of Bodies." Social Research 70(2): 238-251.

MUELLER, Paul S. 2009. "The Terri Schiavo Saga: Ethical and Legal Aspects and Implications for Clinicians.” Polskie Archiwum Medycyny Wewnętrznej 119(9): 574-581.

MURRAY, Stuart J. 2006. "Thanatopolitics: On the Use of Death for Mobilizing Political Life.” Polygraph 18: 191-215.

NETTLETON, Sarah. 2000. "Governing the Risky Self: How to Become Healthy, Wealthy and Wise." Pp. 207-222 in Foucault, Health and Medicine, edited by Alan PETERSEN and Robin BUNTON. London: Routledge.

NOYS, Benjamin. 2005. The Culture of Death. Oxford: Berg Publishers.

QUILL, Timothy E. 2005. "Terri Schiavo - a Tragedy Compounded." New England Journal of Medicine 352(16): 1630-1633.

ROSE, Nikolas. 2007. The Politics of Life Itself: Biomedicine, Power, and Subjectivity in the Twenty-first Century. Princeton, NJ: Princeton University Press.

ROSENEIL, Sasha and Shelley BUDGEON. 2004. "Cultures of Intimacy and Care Beyond 'The Family': Personal Life and Social Change in the Early 21 st Century.” Current Sociology 52(2): 135-159.

ROSENEIL, Sasha. 2010. "Intimate Citizenship: A Pragmatic, Yet Radical, Proposal for a Politics of Personal Life.” European Journal of Women's Studies 17(1): 77-82.

SCHICKTANZ, Silke, Aviad RAZ and Carmel SHALEV. 2010. "The Cultural Context of Patient's Autonomy and Doctor's Duty: Passive Euthanasia and Advance Directives in Germany and Israel." Medicine, Health Care and Philosophy 13(4): 363-369.

SEXTON, Richard, E. and Virginia STAUDT SEXTON. 1982. "Intimacy, a Historical Perspective.” Pp. 1-23 in Intimacy, edited by Martin FISCHER and George STRICKER. Plenum Press: New York and London.

VIDO, Roman. 2011. “Smrt blízká či vzdálená?” Sociální Studia 8(2): 7-12.

YANOW, Dvora. 2007. "Interpretation in Policy Analysis: On Methods and Practice." Critical Policy Analysis 1: 110-122.

ZELIZER, Viviana. 2005. Purchase of Intimacy. Princeton, NJ: Princeton University Press.

\section{Author}

Anna Durnová works at the University of Vienna where she researches the role of discourse and emotions in public politics, especially in health care. In the past, she was as a visiting professor at the Masaryk University in Brno and lectured at the universities in Lyon, Essex, London, Paris and Prague. She is the editor of Critical Policy Studies and an external analyst in Hospodářské noviny.

Contact: anna.durnova@univie.ac.at 